\title{
Influence of Chemical Properties of Wheat-Lupine Flour Blends on Cake Quality
}

\author{
Abdelrahman R. Ahmed ${ }^{1,2, *}$ \\ ${ }^{1}$ Faculty of Specific Education, Home Economics Department, Ain Shams University, Cairo, Egypt \\ ${ }^{2}$ Institute for Food Technology and Food Chemistry, Department of Food Rheology, Technical University of Berlin, Sekr, KL-H1, \\ Königin-Luise-Str, Berlin / Germany \\ *Corresponding author: abdohat1@yahoo.com
}

Received March 01, 2014; Revised March 13, 2014; Accepted March 23, 2014

\begin{abstract}
Legumes have interesting nutritional properties and their inclusion in diet is encouraged; their incorporation into bakery products could be a good method for increasing consumption. In this study, the influence of the partial replacement of wheat flour by lupine flour on the quality characteristics of butter cake was analyzed. In the present study, three different concentrations (5, 10 and $15 \%$ as a substitution of wheat flour) of lupine flour were used. Lupine flour showed higher levels of moisture, crude protein, ash, crude fat and dietary fiber than the wheat flour. The lupine flour showed higher levels of phenolic and flavonoids than the wheat flour. Conversely, wheat flour showed higher levels of total flavonols. Results clearly indicate that lupine flour exhibited higher antioxidant activity with DPPH and ABTS than the wheat flour. Essential amino acids (lysine, threonine, isoleucine, phenylalanine and tryptophane) in lupine flour were higher than those in wheat flour except methionine content which was higher in wheat flour $(1.7 \mathrm{~g} / \mathrm{kg})$. A sensory acceptability of the cake is satisfactory up to $10 \%$ concentration of lupine flour given. Even though deterioration in the structural formation in the batter system after the addition of lupine flour were detected that the blends have relatively good structure due to dominance of wheat to bake acceptable, protein enriched consumable cake. Finally, lupine flour up to $10 \%$ can be used successfully in bakery products. This could be utilized for the development of composite blends from locally produced lupine at small scale industry level as value-add products.
\end{abstract}

Keywords: lupine, phenolic compounds, amino acids, cake quality

Cite This Article: Abdelrahman R. Ahmed, "Influence of Chemical Properties of Wheat-Lupine Flour Blends on Cake Quality.” American Journal of Food Science and Technology, vol. 2, no. 2 (2014): 67-75. doi: 10.12691/ajfst-2-2-4.

\section{Introduction}

Cakes are important bakery products. Their worldwide market currently grows with about $1.5 \%$ a year. Challenges in the cake market include cost reduction, increased shelf life and quality control. Cake making consists of mixing the ingredients into a batter which, because of the high level of liquid phase in cake recipes, has a low viscosity, and baking such batter into cake [1].

Wheat-flours used in cake elaboration have lower protein content, and it is known that one of the most important characteristics of cake elaboration flours is particle size [2]. Gluten does not play an important role in this kind of product, which means that flours from other cereals $[3,4,5]$ or even from pulses, such as chickpeas or lupine $[6,7]$ can be used.

Pulses, also known as grain legumes, are essential to human diets in many parts of the world [8]. Pulses are unique for a human diet in terms of their nutritional profile. They are rich in protein, carbohydrates, dietary fiber, some minerals and vitamins and they are also low in fat $[9,10,11]$.
Legume/pulse proteins, because of their composition, are considered a good supplement for cereal based foods, since both legume and cereal proteins are complementary with regard to their essential amino acids. Legume proteins are rich in lysine and deficient in sulphurcontaining amino acids, whereas cereal proteins are deficient in lysine, but have adequate amounts of sulphur amino acids [12]. Apart from being nutritious, pulse proteins are highly functional and exhibit properties like solubility, gelation and water binding playing a crucial role in structure formation and mouth feel of the finished products. Among the legumes/ pulses tested as proteinenriching agents of bakery products, in the form of various protein preparations (e.g. flour, protein isolate, etc.), are soybean, chickpea, pea and lupine $[6,13,14,15,16,17]$.

Research has indicated that consumption of pulses may have potential health benefits including reduced risk of cardiovascular disease, cancer, type-2 diabetes, osteoporosis, hypertension, gastrointestinal disorders, adrenal disease and reduction of LDL cholesterol [18-26].

The consumption could be higher if the food industry and professional organizations take up the challenge to incorporate grain legumes in novel, convenient and healthy food products [27]. Because of the nutritional and 
health promoting properties of the pulses, the development of value-added pulse based products for new market opportunities in the functional food and nutraceutical industry is being promoted [28].

Lupine flour is a novel food ingredient derived from the endosperm of lupine, a grain legume. It contains 40-45\% protein, 25-30\% fiber, and negligible sugar and starch [29]. It can be incorporated into high carbohydrate foods, resulting in significant increases in protein and fiber, reductions in refined carbohydrate, and little change in product acceptability [30]. Increasing protein at the expense of refined carbohydrate in the diet may benefit blood pressure. Therefore, the aim of this study was to determine the effect of the partial replacement of wheat flour by lupine flour on the quality of cakes.

\section{Materials and Methods}

\subsection{Materials}

Local Egyptian breeds of lupine (Lupinus albus $L$. variety Giza) were obtained from the Agricultural Research Centre, Giza, Egypt. Lupine flour was obtained after grinding lupine grains in a laboratory hammer mill (Retsch - Germany) until they could pass through a 250 $\mu \mathrm{m}$ screen. Commercial wheat flour type 405 was obtained from Lidl Market (Berlin-Germany). All other chemical reagents used in the experimental analysis were of analytical grade.

\subsection{Chemical Analysis}

\subsubsection{Proximate Composition}

Proximate composition was carried out according to ICC Standard Methods [31]. Moisture content was determined by drying the samples at $105^{\circ} \mathrm{C}$ to constant weight (ICC 109/01). Ash content was determined by calcinations at $900^{\circ} \mathrm{C}$ (ICC 104/1). Nitrogen content was determined by using Kieldahl method with factor of 5.7 to determine protein content (ICC 105/2). The total lipid content was determined by defeating in the Soxhelt apparatus with hexane (ICC 136). The determination of starch content was assessed using a polarimetric method according to Ewers, modified by [32]. All the measurements of analyzed samples were made in triplicate.

\subsubsection{Determination of Total Phenolics}

Total phenolic content was determined by the FolinCiocalteu micro-method [33]. A $20 \mu \mathrm{L}$ aliquot of extract solution was mixed with $1.16 \mathrm{~mL}$ of distilled water and $100 \mu \mathrm{L}$ of Folin-Ciocalteu's reagent followed by $300 \mu \mathrm{L}$ of $200 \mathrm{~g} \mathrm{~L}^{-1} \mathrm{Na}_{2} \mathrm{CO}_{3}$ solution. The mixture was incubated in a shaking incubator at $40^{\circ} \mathrm{C}$ for $30 \mathrm{~min}$ and its absorbance at $760 \mathrm{~nm}$ was measured. Gallic acid was used as standard for the calibration curve. Total phenolic content expressed as gallic acid equivalent (GAE) was calculated using the following linear equation based on the calibration curve:

$$
A b=0.98 C+9.925 * 10^{-3}\left(R^{2}=0.9996\right)
$$

where $A b$ is the absorbance and $C$ is the concentration (mg GAE g ${ }^{-1}$ dry weight (DW)).

\subsubsection{Determination of Total Flavonoids}

Total flavonoid content was determined by the method of Ordoñez et al., [34]. A $0.5 \mathrm{~mL}$ aliquot of $20 \mathrm{~g} \mathrm{~L}^{-1} \mathrm{AlCl}_{3}$ ethanolic solution was added to $0.5 \mathrm{ml}$ of extract solution. After $1 \mathrm{~h}$ at room temperature the absorbance at $420 \mathrm{~nm}$ was measured. A yellow color indicated the presence of flavonoids. Extract samples were evaluated at a final concentration of $0.1 \mathrm{mg} \mathrm{ml}{ }^{-1}$. Total flavonoid content expressed as quercetin equivalent (QE) was calculated using the following equation based on the calibration curve:

$$
C=0.0255 * A b\left(R^{2}=0.9812\right)
$$

where $A b$ is the absorbance and $C$ is the concentration (mg QE g ${ }^{-1} \mathrm{DW}$ ).

\subsubsection{Determination of Total Flavonols}

Total flavonol content was determined by the method of Kumaran and Joel Karunakaran, [35]. To $2 \mathrm{~mL}$ of extract solution, $2 \mathrm{~mL}$ of $20 \mathrm{~g} \mathrm{~L}^{-1} \mathrm{AlCl}_{3}$ ethanolic solution and 3 $\mathrm{mL}$ of $50 \mathrm{~g} \mathrm{~L}^{-1}$ sodium acetate solution were added. The absorption at $440 \mathrm{~nm}$ was read after $2.5 \mathrm{~h}$ at $20^{\circ} \mathrm{C}$. Extract samples were evaluated at a final concentration of $0.1 \mathrm{mg}$ $\mathrm{mL}^{-1}$. Total flavonol content expressed as QE was calculated using the same equation of flavonoids.

\subsection{Antioxidant Activity of Extracts}

Because of the differences among the various test systems available, the results of a single method can provide only a limited assessment of the antioxidant properties of a substance [36]. For that reason, in this study the antioxidant capacity of each extract was determined through two complementary assay procedures.

\subsubsection{DPPH Radical-Scavenging Activity}

The DPPH assay according to Lee et al., [37] was utilised with some modifications. The stock reagent solution ( $\left.1 \times 10^{-3} \mathrm{~mol} \mathrm{~L}^{-1}\right)$ was prepared by dissolving 22 $\mathrm{mg}$ of DPPH in $50 \mathrm{~mL}$ of methanol and stored at $-20^{\circ} \mathrm{C}$ until use. The working solution $\left(6 \times 10^{-5} \mathrm{~mol} \mathrm{~L}^{-1}\right)$ was prepared by mixing $6 \mathrm{~mL}$ of stock solution with $100 \mathrm{~mL}$ of methanol to obtain an absorbance value of $0.8 \pm 0.02$ at $515 \mathrm{~nm}$, as measured using a spectrophotometer. Extract solutions of different concentrations $(0.1 \mathrm{~mL}$ of each) were vortexed for $30 \mathrm{~s}$ with $3.9 \mathrm{~mL}$ of DPPH solution and left to react for $30 \mathrm{~min}$, after which the absorbance at 515 nm was recorded. A control with no added extract was also analysed. Scavenging activity was calculated as follows:

$$
\begin{aligned}
& \text { DPPH radical - scavenging activity }(\%) \\
& =\left[\left(A b_{\text {control }}-A b_{\text {sample }}\right) / A b_{\text {control }}\right] * 100
\end{aligned}
$$

where $A b$ is the absorbance at $515 \mathrm{~nm}$.

\subsubsection{ABTS Radical-Scavenging Activity}

For the ABTS assay the method of Re et al., [38] was adopted. The stock solutions were $7 \mathrm{mmol} \mathrm{L}^{-1}$ ABTS solution and $2.4 \mathrm{mmol} \mathrm{\textrm {L } ^ { - 1 }}$ potassium persulfate solution. The working solution was prepared by mixing the two stock solutions in equal quantities and allowing them to 
react for $12-16 \mathrm{~h}$ at room temperature in the dark. Then 1 $\mathrm{mL}$ of the resulting $\mathrm{ABTS}^{+}$solution was diluted with 60 $\mathrm{mL}$ of methanol to obtain an absorbance of $0.706 \pm 0.001$ units at $734 \mathrm{~nm}$, as measured using a spectrophotometer. $\mathrm{ABTS}^{+}$solution was freshly prepared for each assay. Extract solutions of different concentrations (1 mL of each) were allowed to react with $1 \mathrm{~mL}$ of $\mathrm{ABTS}^{+}$solution for 7 min, after which the absorbance at $734 \mathrm{~nm}$ was recorded. A control with no added extract was also analysed. Scavenging activity was calculated as follows:

$$
\begin{aligned}
& \text { ABTS radical - scavenging activity }(\%) \\
& =\left[\left(\mathrm{Ab}_{\text {control }}-\mathrm{Ab}_{\text {sample }}\right) / \mathrm{Ab}_{\text {control }}\right] * 100
\end{aligned}
$$

where $A b_{\text {control }}$ is the absorbance of ABTS radical + methanol $\mathrm{Ab}_{\text {sample }}$ is the absorbance of ABTS radical + extract.

\subsection{HPLC Analysis}

A total of $20 \mathrm{mg}$ grounded dried samples were extracted for 15 min using $750 \mu \mathrm{L} 70 \%$ methanol (v/v, $\mathrm{pH} 4$, phosphoric acid) in an ultrasonic water bath (Sonorex digital 10 p, Bandelin) on ice. Samples were centrifuged for $5 \mathrm{~min}$ at $6000 \mathrm{rpm}$. The supernatants were collected and the pellets were re-extracted twice more with $500 \mu \mathrm{L} 70 \%$ methanol. The combined supernatants from each sample were reduced to near dryness in a centrifugation evaporator (Speed Vac, SC 110) at $25^{\circ} \mathrm{C}$. Samples were then made up to $1 \mathrm{ml}$ with $40 \%$ acetonitrile. The samples were filtrated using $0.22 \mu \mathrm{m}$ filter, and then analyzed with HPLC (Dionex Summit P680A HPLCSystem), equipped with P680 pump, ASI-100 automated sample injector, a Narrow-Bore Acclaim PA C16-column (3 $\mu \mathrm{m}, 2.1 * 150 \mathrm{~mm}$, Dionex) and PSA-100 photodiode array detector (Dionex) and software Chromeleon 6.8 (Dionex, USA). The column was operated at a temperature of $35^{\circ} \mathrm{C}$.

The mobile phase consisted of $0.1 \%(\mathrm{v} / \mathrm{v})$ phosphoric acid in ultrapure water (eluent $\mathrm{A}$ ) and of $40 \%(\mathrm{v} / \mathrm{v})$ acetonitrile in ultrapure water (eluent B). A multistep gradient was used for all separations with an initial injection volume of $40 \mu \mathrm{L}$ and a flow rate of $0.4 \mathrm{~mL} / \mathrm{min}$. The multistep gradient was as follows: $1 \mathrm{~min}: 0.5 \%(\mathrm{v} / \mathrm{v})$ B; 1-10 min: 0.5-40 \% B; 10-12 min: $40 \%$ B; 12-18 min: 40-80 \% B; 18-20 min: 80 \% B; 20-24 min: 80-99 \% B; 24-30 min: 99- 100 \% B; 30-34 min: 100-0.5 \% B; 34-39 min: $0.5 \%$ B. Simultaneous monitoring was performed at 290, 330 and $254 \mathrm{~nm}$ at a flow rate of $0.4 \mathrm{~mL} / \mathrm{min}$. Phenolic acid quantity was calculated from HPLC peak areas at $290 \mathrm{~nm}$ against the internal standard and external standards. Identification and quantification of phenolic acids present was done by comparing retention time and area of the peaks in the extracts with that of the standard phenolic acids (chlorogenic acid, caffeic acid, cinnamic acid, coumaric acid, rosmarinic acid and sinapic acid).

\subsection{Amino Acid Analysis}

Amino acid content was determined as described by Moore et al., [39]. The analysis was performed in Central Service Unit, National Research Centre, Egypt using LC3000 amino-acid analyzer (Eppendorf-Biotronik, Germany). The technique was based on the separation of the amino acids using strong cation exchange chromatography followed by the ninhydrin colour reaction and photometric detection at $570 \mathrm{~nm}$. Standard amino acids were used for comparison of resulting profiles, allowing quantitation of amino-acid residues. The defatted powdered seeds were hydrolyzed with $6 \mathrm{~N} \mathrm{HCl}$ at $110^{\circ} \mathrm{C}$ in teflon capped vials for $24 \mathrm{~h}$. After vacuum removal of $\mathrm{HCl}$, the residues were dissolved in a lithium citrate buffer, $\mathrm{pH}$ 2.2. Twenty $\mu \mathrm{L}$ of the solution were loaded into the cation exchange column (pre-equilibrated with the same buffer), then four lithium citrate buffers with $\mathrm{pH}$ values of 2.2, 2.8, 3.3 and 3.7, respectively, were successively applied to the column at a flow rate of $20 \mathrm{~mL} / \mathrm{min}$. The ninhydrin flow rate was $10 \mathrm{~mL} / \mathrm{h}$ under these conditions and a typical analysis required $160 \mathrm{~min}$.

Methionine was determined as methionine sulfone, after oxidation with performic acid. An amino acid standards containing cysteine were treated parallel with the samples and used to quantify the methionine content. The amino acid content of the reference protein was taken from [40].

\subsection{Cake Formulation and Baking}

The recipes of butter cake used: $100 \mathrm{~g}$ (wheat flour or wheat flour substituted with 5, 10 or $15 \%$ lupine flour), $80 \mathrm{~g}$ egg, $60 \mathrm{~g}$ sugar, $50 \mathrm{ml}$ Milk (1.5 \% fat), $50 \mathrm{~g}$ margarine and $4 \mathrm{~g}$ baking powder. A creaming mixing procedure was used. All ingredients, except for the flour and baking powder, were mixed for 2 min at speed 6 using a Kitchene Aid Professional mixer (KPM5). After the addition of the flour and baking powder, the mixing process continued for $3 \mathrm{~min}$ at speed 8. $200 \mathrm{~g}$ of cake batter were placed into $120 \mathrm{~mm}$ diameter and $45 \mathrm{~mm}$ height, metallic, lard coated pan, and were baked in an electric oven for $25 \mathrm{~min}$ at $200^{\circ} \mathrm{C}$.

\subsection{Loaf Volume Determination}

Cake mass was weighted after 3 hours at room temperature. The volume $\left(\mathrm{cm}^{3}\right)$ was measured by rapeseed replacement method described in the [41]. The specific volume was obtained by dividing the volume by their weights.

\subsection{Color Measurements}

Crust and crumb color of fresh cake was measured with a Minolta Calorimeter (CR 200 Japan). Color readings were expressed by Hunter values for $L^{*}, a^{*}$ and $b^{*}$.

\subsection{Sensory Evaluation}

Evaluation of the cake quality characteristics was carried out following cooling to room temperature for $2 \mathrm{~h}$. Sensory evaluation was performed by ten trained panelists who were graduate students and staff members of the Department of Rheology, Institute of Food Technology and Food Chemistry, Technical University, Berlin. Cakes were randomly assigned to each panelist. The panelists were asked to evaluate each sample for appearance, crumb texture, crumb grain, crust color, taste, odor and overall acceptability. A 10 point scale was used where 10 "excellent and 1" extremely unsatisfactory. 


\subsection{Statistical Analysis}

Analysis of variance (ANOVA) was carried out using SAS program (Statistical Analysis System version. 9.1) SAS Institute Inc. [42]. The chemical composition and cake characteristics of wheat batter with or without lupine flour were analysed using ANOVA. When the treatment factor effect was found significant, indicated by a significant F-test $(p<0.05$ ), differences between the respective means were determined using least significant difference (LSD) and considered significant when $\mathrm{p}<$ 0.05 . Mean \pm standard deviation of mean was used.

\section{Results and Discussion}

\subsection{Chemical Composition of Wheat Flour, Lupine Flour and Their Blends}

Lupine is a good source of nutrients, not only proteins but also lipids, dietary fiber, minerals, and vitamins [43]. The results for the chemical composition of wheat flour (WF), lupine flour (LF), and their blends are shown in Table 1. The lupine flour showed higher levels of moisture, crude protein, ash, crude fat and dietary fiber than the wheat flour. Conversely, wheat flour showed higher levels of starch. Highly significant differences $(P<0.05)$ were observed between the two types of flours. Mean protein and dietary fiber increased with increasing amount of lupine flour added. There was no significant difference between wheat flour and supplemented flour with different concentration of lupine for moisture content (Table 1).

The chemical properties of wheat flours have been studied previously by several researchers and they found that moisture content ranged between 12.5 to $14.6 \%$ crude protein content 8.23 to $12.71 \%$ and ash content 0.42 to 0.66 [44].

Table 1. Chemical composition of wheat flour (WF), lupine flour (LF) and their blends

\begin{tabular}{|c|c|c|c|c|c|}
\hline \multicolumn{7}{|c|}{ Table 1. Chemical composition of wheat flour (WF), lupine flour (LF) and their blends } \\
\cline { 4 - 6 } Analysis & \multirow{2}{*}{ WF } & \multirow{2}{*}{ LF } & 5 & \multicolumn{3}{c|}{ LF level (\%) } \\
\hline Moisture & $11.27 \pm 0.09$ & $12.37 \pm 0.46$ & $11.35 \pm 0.19$ & $11.42 \pm 0.17$ & $11.54 \pm 1.16$ \\
\hline Protein & $12.1 \pm 0.20$ & $38.6 \pm 0.87$ & $13.73 \pm 0.24$ & $14.75 \pm 0.27$ & $16.28 \pm 0.31$ \\
\hline Ash & $0.40 \pm 0.02$ & $3.41 \pm 0.03$ & $0.55 \pm 0.01$ & $0.70 \pm 0.04$ & $0.85 \pm 0.03$ \\
\hline Fat & $1.62 \pm 0.19$ & $9.94 \pm 0.16$ & $2.04 \pm 0.19$ & $2.45 \pm 0.17$ & $2.87 \pm 0.16$ \\
\hline Starch & $69.8 \pm 1.96$ & $0.98 \pm 0.04$ & $66.36 \pm 3.94$ & $62.92 \pm 1.88$ & $59.48 \pm 2.84$ \\
\hline S. D. F & $1.1 \pm 0.09$ & $11.0 \pm 1.36$ & $1.60 \pm 0.14$ & $2.09 \pm 0.27$ & $2.59 \pm 0.31$ \\
\hline I. D. F & $1.6 \pm 0.23$ & $30.8 \pm 2.45$ & $3.06 \pm 0.31$ & $4.52 \pm 0.42$ & $5.98 \pm 0.53$ \\
\hline T. D. F & $2.7 \pm 0.15$ & $41.8 \pm 3.08$ & $4.66 \pm 0.27$ & $6.61 \pm 0.43$ & $8.57 \pm 0.60$ \\
\hline
\end{tabular}

Mean \pm standard deviation. S.D.F: Soluble Dietary Fiber. I.D.F: Insoluble Dietary Fiber. T.D.F: Total Dietary Fiber.

Table 2. Extract yield, total polyphenols content and antioxidant capacity of wheat flour (WF), lupine flour (LF) and their blends

\begin{tabular}{|c|c|c|c|c|c|}
\hline \multirow{2}{*}{ Analysis } & WF & LF & \multicolumn{4}{|c|}{ LF level (\%) } \\
\cline { 4 - 6 } & $13.7 \pm 3.99$ & $36.2 \pm 1.73$ & $11.9 \pm 0.35$ & $13.6 \pm 1.35$ & $14.0 \pm 1.21$ \\
\hline Yield extract (\%) & $126.63 \pm 3.52$ & $138.17 \pm 8.35$ & $132.17 \pm 0.58$ & $142.5 \pm 7.10$ & $156.53 \pm 3.88$ \\
\hline $\begin{array}{c}\text { Total phenolic } \\
(\mu \mathrm{g} \text { GAE/g DW) }\end{array}$ & $6.33 \pm 0.15$ & $8.93 \pm 0.06$ & $7.67 \pm 1.27$ & $7.93 \pm 0.06$ & $8.4 \pm 0.52$ \\
\hline $\begin{array}{c}\text { Total flavonoids } \\
(\mu \mathrm{g} \text { QE/g DW) }\end{array}$ & $32.03 \pm 6.13$ & $31.60 \pm 4.70$ & $29.10 \pm 2.48^{*}$ & $28.27 \pm 2.96^{*}$ & $27.00 \pm 1.08^{*}$ \\
\hline $\begin{array}{c}\text { Total flavonols } \\
(\mu \mathrm{g} \text { QE/g DW) }\end{array}$ & $3.31 \pm 0.35$ & $20.62 \pm 1.22$ & $5.1 \pm 0.10^{*}$ & $6.04 \pm 0.77^{*}$ & $7.16 \pm 0.26^{*}$ \\
\hline DPPH (\%) & $26.7 \pm 0.21$ & $43.42 \pm 0.37$ & $29.41 \pm 0.37^{*}$ & $31.09 \pm 0.00^{*}$ & $32.35 \pm 0.37^{*}$ \\
\hline ABTS (\%) & &
\end{tabular}

Mean \pm standard deviation

Protein content of lupine (38.6 \%) was higher than that of a lot of legumes. Favier et al., [45] reported that haricot bean, lentil and soy bean contain $28.8 \%, 26.7 \%$ and $40.5 \%$ protein, respectively. Because of the high protein content, lupine flour could be used in the human diet. Also, temperature of denaturation of these proteins is higher than animal protein, so they are technologically easier to handle [46]. Lupine flour had a high amount of crude fiber (16.2 \%). These fibers have many desirable properties, including white color, high water-holding capacity (7.1 g $\mathrm{H}_{2} \mathrm{O} / \mathrm{g}$ ) and beneficial effects on human health [47]. Therefore, lupine flour can be incorporated into a wide range of foods to make dietary products.

\subsection{Phenolic Compounds and Antioxidants Capacity of Wheat Flour, Lupine Flour and Their Blends}

Phenolic compounds ubiquitous in plants are key phytochemical drivers of the health and functional foods and nutraceutical industry. Research with polyphenol compounds from various crops has created a growing market for polyphenol-rich ingredients, estimated to be worth around \$ 99 million in Europe in 2003 [48].

Conventional solvent extraction has been reported in a laboratory scale using acetone, hexane, methanol and ethanol [49]. In this study, methanol was used for the extraction of antioxidant compounds from wheat, lupine flour and their blends (Table 2). The extraction yield 13.7 and $36.2 \mathrm{~g} / 100 \mathrm{~g}$ dry weight for wheat and lupine flour respectively.

The lupine flour showed higher levels of total phenolic and total flavonoids than the wheat flour. Conversely, wheat flour showed higher levels of total flavonols. These results confirmed by statistical analysis, which highly significant differences $(\mathrm{P}<0.05)$ were observed between the two type of flours. Total phenolic and total flavonoids increased with increasing amount of lupine flour added to be $132.17 \pm 0.58,142.5 \pm 7.10,156.53 \pm 3.88(\mu \mathrm{g} \mathrm{GAE} / \mathrm{g}$ DW) and $7.67 \pm 1.27,7.93 \pm 0.06,8.4 \pm 0.52(\mu \mathrm{g} \mathrm{QE} / \mathrm{g}$ DW) for substituting wheat flour with lupine flour at 5,10 and $15 \%$, respectively on dry weight basis. The contents of phenolic acids in lupine used in this study are comparable to levels reported previously [50], especially 
in cultivars of L. albus grown in Portugal. Phenolic content of lupins were higher than those of bean cultivars grown in Manitoba [51] probably as a result of relatively high flavonoid content. The methanolic extracts of lupine seed were analysed by high performance liquid chromatography figure 15 .

As shown in figure 1 , nine phenolic acids were separated and identified. This method is well reproducible and provides good separation in terms of migration time and resolution.

The antioxidant effects of extracts of various wheat flour (WF), lupine flour (LF) and their blends at different concentration (5, 10 and $15 \%$ ) were measured. Since the active substances of flour extracts tested are different, the antioxidant activities of these extracts cannot be evaluated by only a single method. Therefore, two different models were used in this study [52].

Free radicals which are involved in the process of lipid peroxidation are considered to play a major role in numerous chronic pathologies, such as cancer and cardiovascular diseases among others [53]. The DPPH radical has been widely used to evaluate the free radicals' scavenging ability of various natural products and has been accepted as a model compound for free radicals originating in lipids [54]. The effect of antioxidants on diphenyl-p-picryl hydrazyl (DPPH) radical scavenging was thought to be due to their hydrogen donating ability. $\mathrm{DPPH}$ is a stable free radical and accepts an electron or hydrogen radical to become a stable diamagnetic molecule.
The assay is based on the reduction of DPPH. Because of its odd electron, DPPH gives strong absorption maxima at $515 \mathrm{~nm}$ (purple color) by visible spectroscopy. As the odd electron of the radical becomes paired off in the presence of a hydrogen donor, i.e., a free radical scavenging antioxidant, the absorption intensity is decreased, and the resulting decolorization is stochiometric with respect to the number of electrons captured [55].

Table 2 showed that the scavenging activity of methanolic extracts against DPPH for wheat flour (WF), lupine flour (LF) and their blends. Significant $(p<0.05)$ differences between wheat and lupine flour extracts were observed. Results clearly indicate that lupine flour exhibited higher antioxidant activity with DPPH and ABTS than the wheat flour. The antioxidant activity increased with increasing amount of lupine flour added to be $5.1 \pm 0.10,6.04 \pm 0.77,7.16 \pm 0.26$ in DPPH and $29.41 \pm$ $0.37,31.09 \pm 0.00,32.35 \pm 0.37$ in ABTS respectively, for substituting wheat flour with lupine flour at 5, 10 and $15 \%$, respectively on dry weight basis.

Wang et al., [56] found that some compounds which have $\mathrm{ABTS}^{+}$scavenging activity did not show DPPH scavenging activity. In this study, there was not the case. The $\mathrm{ABTS}^{+}$scavenging data suggests that the components within the extracts are capable of scavenging free radicals via a mechanism of electron/hydrogen donation and should be able to protect susceptible matrices from free radical-mediated oxidative degradation.

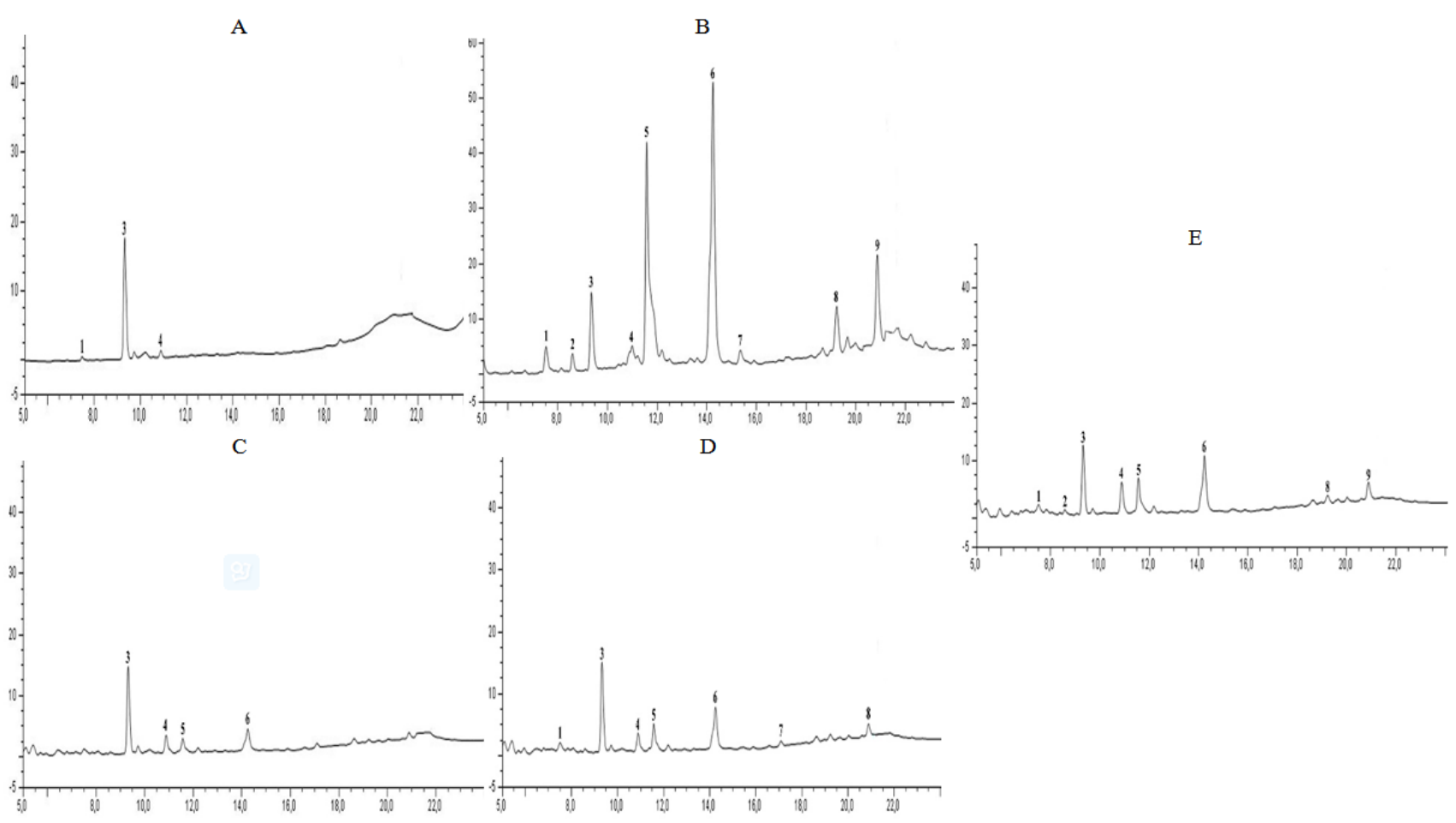

Figure 1. HPLC chromatogram of methanol extract of: wheat flour (A), lupine flour (B) and wheat flour supplemented with lupine flour at different concentration, $5 \%$ (C). $10 \%$ (D) and $15 \%$ (E). 1. gallic, 2. procatechuic, 3. p-hydroxybenzoic, 4. vanillin, 5. P coumaric, 6. chlorogenic, 7. cinnamic 8. sinapine and 9. ferulic acid

\subsection{Amino Acids Content}

Lupine seeds represent a good balance of essential amino acids [57]. They are considered to be a good source of lysine, and are generally poor in the sulfur-containing amino acids (methionine and cysteín) [58] and threonine [59].

The results for the amino acid content of wheat flour (WF) and lupine flour (LF) are shown in Table 3. In contrast to plants, humans and animals are able to synthesize only 9 amino acids used in protein synthesis 
(non-essential amino acids). The biosynthesis of the remaining (essential) amino acids, thereby the protein synthesis, is not possible without their continuous supply through food consumption. In the case of low-protein diets, symptoms, such as delay in growth, negative nitrogen uptake or disturbances in protein synthesis, can take place. Therefore foods rich in exogenous amino acids are desirable.

Table 3. The total amino acids \% dry matter, for wheat (WF) and lupine flour (LF)

\begin{tabular}{|c|c|c|c|c|c|c|c|}
\hline Amino Acid g/kg & WF & $\mathrm{LF}$ & $\mathrm{FAO} / \mathrm{WHO} * *$ & Amino Acid g/kg & $\mathrm{FAO} / \mathrm{WHO}$ & WF & $\mathrm{LF}$ \\
\hline Lysin* & $3,0 \pm 0.13$ & $16.35 \pm 0.56$ & 5.8 & Leucin & 6.6 & $6,7 \pm 0.12$ & $26.13 \pm 1.08$ \\
\hline Threonin* & $2,7 \pm 0.08$ & $11.48 \pm 0.47$ & 3.4 & Phenylalanin* & 6.3 & $4,1 \pm 0.16$ & $14.20 \pm 0.40$ \\
\hline Valin & $4,8 \pm 0.28$ & $16.65 \pm 0.76$ & 3.5 & Tyrosin & 6.1 & $2,6 \pm 0.10$ & $13.90 \pm 0.53$ \\
\hline Methionin* & $1,7 \pm 0.15$ & $1.59 \pm 0.16$ & 2.5 & Tryptophan* & 1.1 & $1,4 \pm 0.07$ & $10.94 \pm 0.70$ \\
\hline Serine & $2,3 \pm 0.50$ & $1.52 \pm 0.60$ & - & Arginin & - & $4,3 \pm 0.18$ & $36.13 \pm 3.78$ \\
\hline Isoleucin* & $3,4 \pm 0.20$ & $14.85 \pm 0.36$ & 2.8 & Histidin & 1.9 & $2,5 \pm 0.19$ & $5.89 \pm 0.33$ \\
\hline
\end{tabular}

*Essential Amino Acids **FAO/WHO, [40]

The results showed that the essential amino acids (lysine, threonine, isoleucine, phenylalanine and tryptophane) in lupine flour were higher than those in wheat flour except methionine content which was higher in wheat flour $(1.7 \mathrm{~g} / \mathrm{kg})$. This result was confirmed by Lubowicki et al., [60]. Sujak et al., [61] reported that lupine seeds of different species representing diverse varieties of sweet lupine grown in Poland manifest a large deficiency of sulphur containing amino acids, for which the recommended level is $3.5 \mathrm{~g} / 16 \mathrm{~g} \mathrm{~N}$ [62]. Methionine levels of $1.59 \mathrm{~g} / \mathrm{kg}$, found for the lupine flour was low but comparable to results reported previously for other lupins [63]. The recommended level of methionine is $2.5 \mathrm{~g} / \mathrm{kg}$ [64]. Of great importance is the presence of sulphur containing amino acids, mainly methionine, which is necessary for the synthesis of cysteine, as well as phenylalanine needed for the synthesis of tyrosine [62].

The protein demand of different organisms depends on their physiological state stipulated mainly by age. For example, young and growing mammals (up to approximately two years in humans) need proteins rich in amino acids, such as arginine and histidine, as such amino acids are the source of the active centers of many enzymes. In contrast, adults show almost no physiological demand for these amino acids.

From the results we can noticed that lupine flour is rich with arginine and histidine (36.13 and $5.89 \mathrm{~g} / \mathrm{kg}$ respectively). Protein quantity, as well as composition, is the limitation of protein quality [64]. For humans, adequate quantities of lysine, methionine and tryptophan are considered necessary in food of high nutritive value [62]. A number of approaches, based on the analysis of amino acids, have been considered for the estimation of protein quality in human and fodder foods. According to Alsmeyer et al., [65], the nutritional value of food should be expressed in terms of leucine and tyrosine contents, while other classifications are based on the chemical scores for 9-11 amino acids considered essential. Lupine flour showed high content of lysine $(16.35 \mathrm{~g} / \mathrm{kg}$ ) more than wheat flour $(3.0 \mathrm{~g} / \mathrm{kg})$.

\subsection{Influence of Lupine Flour Incorporation on Cake Properties}

According to Table 4, cake height diminished as the lupine flour percentage increased. During the baking process, baking powder generates gases, which should be retained in order to guarantee good cake volume, and in that respect flour quality has an important role to play. Another important factor is the gelatinization temperature of the flour, as Howard, [66], pointed out for layer cakes, whereas Mizukoshi et al., [67] reached the same conclusion for sponge cakes. The starch gelatinization at low temperatures would prevent the correct expansion of dough.

Table 4. Cake characteristics of wheat flour and lupine flour composite flours

\begin{tabular}{|c|c|c|c|c|}
\hline Sample & Cake height cm & Cake weight g & Cake volume $\mathrm{cm}^{3}$ & Specific volume $\mathrm{cm}^{3} / \mathrm{g}$ \\
\hline WF & $7.5 \pm 0.53$ & $265.1 \pm 13$ & $660 \pm 56$ & $2.49 \pm 0.6$ \\
\hline LF 5 \% & $7.0 \pm 0.33$ & $265.2 \pm 38$ & $670 \pm 46$ & $2.53 \pm 0.45$ \\
\hline LF 10\% & $6.5 \pm 0.23$ & $264.5 \pm 11$ & $700 \pm 68$ & $2.61 \pm 0.27$ \\
\hline LF 15\% & $6.0 \pm 0.65$ & $269.2 \pm 8$ & $2.60 \pm 0.30$ & \\
\hline
\end{tabular}

Mean \pm standard deviation of mean.

Lupine flour also presented higher protein content, and different amino acid composition than wheat flours which could affect cake characteristics, especially volume [68]. As far as lupine derivatives are concerned, flour gave cakes with higher volume. This fact can be explained by the higher fiber content of lupine flour and its effect on pasting behavior of starches [69].

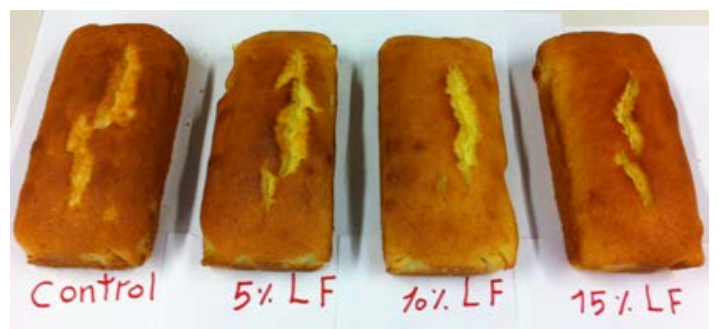

Figure 2. Comparison of the baking properties of wheat flour and mixes with lupine flour cake
The volume index is an indicator of cake volume and, as expected, followed a similar tendency as volume. Symmetry indicates the differences in height between the central zone and the lateral zone. Thus, a high symmetry suggests that cakes mainly rise in their central part, while a negative symmetry indicates that cake volume falls down at the end of the baking process. Hence, symmetry gives an idea about gas retention in the final baking phase. In both cases the incorporation of lupine flour at different levels had no effect on cake symmetry (Figure 2).

This result is not confirmed with Gômez et al., [6] who studied the influence of the total or partial replacement of wheat flour by chickpea flour on the quality characteristics of two kinds of cake. They reported that in both cases the incorporation of chickpea flour reduced their symmetry, and in the case of layer cakes with $100 \%$ of chickpea flour it became negative. As for cake weight, no significant differences were found. Therefore, the water 
retention capacity was not affected by the substitution of wheat flour by lupine flour.

Crust color in cakes varied with the quantity and the kind of lupine flour addition. This influence was more important in cakes. The crust color data of cakes are shown in Table 5 Cakes became darker (lower $\mathrm{L}^{*}$ ) as the lupine flour quantity increased. With regard to the wheat flour, it produced the brightest cakes. No considerable differences in crust yellowness were found among the different lupine flour samples, while all lupine flour gave higher b values than the control (wheat flour). The crust color of cakes was generated in the baking process due to the Maillard reactions between sugars and amino acids, and the caramelization process of sugars. Therefore, the differences observed when the quantity of lupine flour increased could be attributed to the high protein content and the different amino acid composition of the composite flours compared to the wheat flour.

Table 5. Color measurements of cake from wheat flour and lupine flour composite flours

\begin{tabular}{|c|c|c|c|c|c|c|}
\hline \multirow{2}{*}{ Color parameters } & \multicolumn{3}{|c|}{ Crust } & \multicolumn{3}{|c|}{ Crumb } \\
\hline & $\mathrm{L}^{*}$ & $a^{*}$ & $\mathrm{~b}^{*}$ & $\mathrm{~L}^{*}$ & $a^{*}$ & $\mathrm{~b}^{*}$ \\
\hline WF & $90.53 \pm 3.79$ & $1.24 \pm 0.69$ & $4.92 \pm 2.74$ & $93.62 \pm 3.74$ & $0.90 \pm 0.60$ & $2.31 \pm 1.58$ \\
\hline LF $5 \%$ & $76.48 \pm 8.24$ & $4.19 \pm 1.85$ & $11.88 \pm 6.20$ & $92.39 \pm 1.61$ & $1.32 \pm 0.41$ & $2.55 \pm 1.59$ \\
\hline LF $10 \%$ & $74.38 \pm 10.43$ & $4.71 \pm 2.09$ & $14.22 \pm 3.13$ & $92.15 \pm 2.31$ & $3.00 \pm 0.50$ & $7.78 \pm 1.82$ \\
\hline LF $15 \%$ & $73.44 \pm 4.50$ & $4.94 \pm 4.05$ & $15.95 \pm 1.76$ & $91.48 \pm 1.55$ & $4.89 \pm 30$ & $11.99 \pm 1.73$ \\
\hline
\end{tabular}

Mean \pm standard deviation of 10 different points on Crust and Crumb.

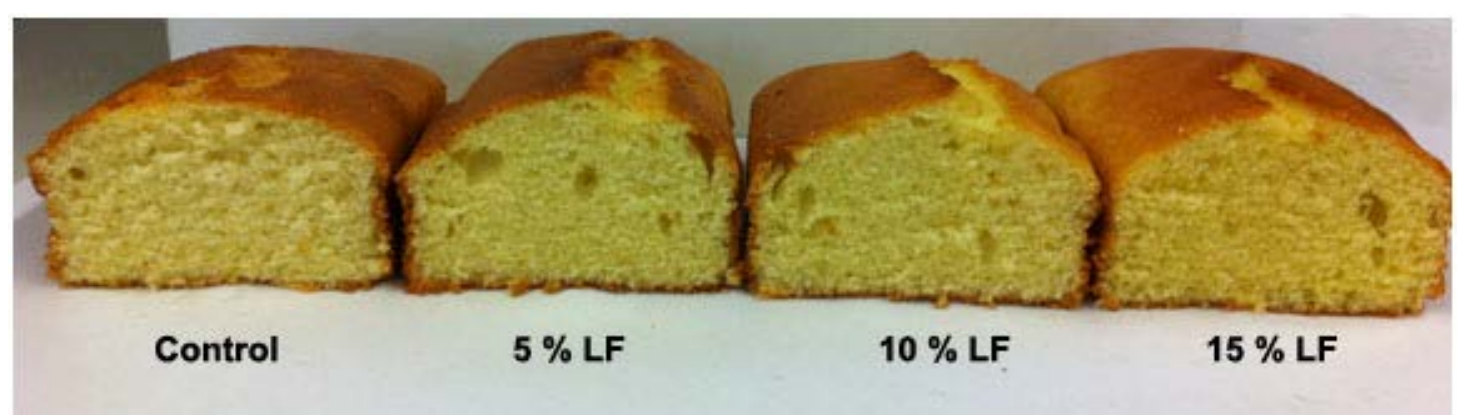

Figure 3. Crumb color of wheat flour and mixes with lupine flour cake

Table 6. Sensory evaluation of cake from wheat flour and lupine flour composite flours

\begin{tabular}{|c|c|c|c|c|c|c|c|}
\hline Sample & Appearance & Crumb texture & Crumb grain & Crust color & Taste & Odor & Overall acceptability \\
\hline WF & $7.9 \pm 1.5$ & $7.9 \pm 1.5$ & $7.1 \pm 1.6$ & $7.6 \pm 1.8$ & $7.7 \pm 2.1$ & $8.1 \pm 1.9$ & $8.2 \pm 1.3$ \\
\hline LF 5 \% & $7.7 \pm 2.0$ & $8.1 \pm 1.1$ & $7.9 \pm 0.9$ & $8.3 \pm 1.6$ & $7.8 \pm 1.8$ & $8.2 \pm 1.6$ & $8.1 \pm 1.5$ \\
\hline LF 10\% & $8.0 \pm 1.4$ & $8.0 \pm 1.5$ & $8.3 \pm 0.9$ & $8.1 \pm 1.5$ & $7.4 \pm 2.2$ & $7.9 \pm 1.8$ & $8.1 \pm 1.2$ \\
\hline LF 15\% & $8.6 \pm 1.3$ & $7.7 \pm 2.1$ & $8.9 \pm 1.5$ & $8.7 \pm 1.3$ & $8.2 \pm 2.0$ & $8.2 \pm 1.1$ & $8.7 \pm 1.3$ \\
\hline
\end{tabular}

Mean \pm standard deviation of ten panellists

Cake crumb does not reach temperatures above $100^{\circ} \mathrm{C}$, so the Maillard or caramelization reactions by sugars fail to take place. Therefore, crumb color must be the result of the raw materials colors and their interactions. The crumb color data of cakes are shown in Table 5 and Figure 3 Cake crumb of lupine flour samples were lightly darker than control, and the lupine flour addition reduced its luminosity, but this effect was not significant. These results agree with those obtained by Dodok et al., [70], who observed that chickpea flour triggered the change in the crumb color when they studied the addition of chickpea flour to bread dough.

Sensory evaluation results of fortified cake with lupine flour are presented in Table 6. It was found that cake which was fortified with different levels of lupine flour had non significant difference in taste, odour and overall acceptability as compared to unfortified cake (control).

The present results came in agreement with Sabanis et al., [71] who reported that, organoleptic properties (colour, flavour and overall acceptability) improved with a low proportion of chickpea flour, especially for $5 \% \mathrm{w} / \mathrm{w}$ substitution. Alabi and Anuonye, [72] indicated that up to $50 \%$ of some legume products could be added without significant loss in palatability.

\section{Conclusion}

This study demonstrates that it is possible to incorporate lupine flour into cake formulations up to $10 \%$. The substitution percentage lupine flour used led to the pursued objectives (nutritional improvement, free-gluten products, special organoleptic characteristics, etc.). This could be utilized for the development of composite blends from locally produced lupine at small scale industry level as value-add products.

\section{References}

[1] Cauvain SP, Young L: Baked products. in Science, technology and practice. Oxford, UK: Blackwell Publishing, 2006.

[2] Gómez M, Ruiz-París E, Oliete B: Original article: Influence of flour mill streams on cake quality. International Journal of Food Science \& Technology 2010; 45: 1794-1800.

[3] Oliete B, Pérez GT, Gómez M, Ribotta PD, Moiraghi M, León AE: Use of wheat, triticale and rye flours in layer cake production. International Journal of Food Science \& Technology 2010; 45: 697-706.

[4] Ronda F, Gomez M, Caballero PA, Oliete B, Blanco CA: Improvement of quality of gluten-free layer cakes. Food Science and Technology International 2009; 15: 193-202.

[5] Turabi E, Sumnu G, Sahin S: Rheological properties and quality of rice cakes formulated with different gums and an emulsifier blend. Food Hydrocolloids 2008; 22: 305-312.

[6] Gômez M, Oliete B, Rosell CM, Pando V, Fernandez E: Studies on cake quality made of wheat_chickpea flour blends. LWT Food Science and Technology 2008; 41: 1701-1709. 
[7] Paraskevopoulou A, Chrysanthou A, Koutidou M: Characterisation of volatile compounds of lupin protein isolate enriched wheat flour bread. Food Research International 2012; 48: 568-577.

[8] Roy F, Boye JI, Simpson BK: Bioactive proteins and peptides in pulse crops: Pea, chickpea and lentil. Food Research International 2010; 43:4 32-442.

[9] Iqbal A, Khalil IA, Ateeq N, Khan MS: Nutritional quality of important food legumes. Food Chemistry 2006; 97: 331-335.

[10] Rochfort S, Panozzo J: Phytochemicals for Health, the Role of Pulses. Journal of Agricultural and Food Chemistry 2007; 55: 7981-7994.

[11] Tosh SM, Yada S: Dietary fibres in pulse seeds and fractions: Characterization, functional attributes, and applications. Food Research International 2010; 43: 450-460.

[12] Eggum BO, Beame RM: The nutritive value of seed proteins. in Muller WGPH (ed): Seed protein biochemistry, genetics and nutritive value. Junk: The Hague, 1983, 499-531.

[13] Doxastakis G, Zafiriadis I, Irakli M, Tananaki C: Lupin, soya and triticale addition to wheat flour doughs and their effect on rheological properties. Food Chemistry 2002; 77: 219-227.

[14] Kiosseoglou V, Paraskevopoulou A: Functional and physicochemical properties of pulse proteins. in B. Tiwari AG, \& B. McKenna (ed): Pulse foods: Processing, quality and nutraceutical application. Burlington: Elsevier Inc. Academic Press, 2011, 57-90.

[15] Paraskevopoulou A, Provatidou E, Tsotsiou D, Kiosseoglou V: Dough rheology and baking performance of wheat flour-lupin protein isolate blends. Food Research International 2010; 43: 1009-1016.

[16] Ribotta PD, Arnulphi SA, Leôn AE, Anôn MC: Effect of soybean addition on the rheological properties and breadmaking quality of wheat flour. Journal of the Science of Food and Agriculture 2005; 85: 1889-1896.

[17] Sadowska J, Blaszczak W, Fornal J, Vidal-Valverde C, Frias J: Changes of wheat dough and bread quality and structure as a result of germinated pea flour addition. Eur Food Res Technol 2003; 216: 50 .

[18] Anderson JW, Major AW: Pulses and lipaemia, short- and longterm effect: potential in the prevention of cardiovascular disease. Br J Nutr 2002; 88 S 263-271.

[19] Bazzano LA, He J, Ogden LG, Loria C, Vupputuri S, Myers L, Whelton PK: Legume consumption and risk of coronary heart disease in US men and women: NHANES I Epidemiologic Follow-up Study. Arch Intern Med 2001; 161: 2573-2578.

[20] Bazzano LA, Thompson AM, Tees MT, Nguyen CH, Winham DM: Non-soy legume consumption lowers cholesterol levels: a meta-analysis of randomized controlled trials. Nutr Metab Cardiovasc Dis 2011; 21: 94-103.

[21] Campos-Vega R, Loarca-Piña G, Oomah BD: Minor components of pulses and their potential impact on human health. Food Research International 2010; 43: 461-482.

[22] Cao JJ, Gregoire BR, Sheng X, Liuzzi JP: Pinto bean hull extract supplementation favorably affects markers of bone metabolism and bone structure in mice. Food Research International 2010; 43: 560-566.

[23] Jacobs DR, Jr., Gallaher DD: Whole grain intake and cardiovascular disease: a review. Curr Atheroscler Rep 2004; 6: 415-423.

[24] Mathers JC: Pulses and carcinogenesis: potential for the prevention of colon, breast and other cancers. Br J Nutr 2002; $88 \mathrm{~S}$ 273-279.

[25] Tharanathan RN, Mahadevamma S: Grain legumes - a boon to human nutrition. Trends Food Sci. Technol. 2003; 14: 507.

[26] Venn BJ, Mann JI: Cereal grains, legumes and diabetes. Eur J Clin Nutr 2004; 58: 1443-1461.

[27] Schneider AV: Overview of the market and consumption of pulses. Br. J. Nutr. 2002; 88: S 243.

[28] Anton AA, Ross KA, Lukow OM, Fulcher RG, Arntfield SD: Influence of added bean flour (Phaseolus vulgaris L.) on some physical and nutritional properties of wheat flour tortillas. Food Chemistry 2008; 109: 33-41.

[29] Evans AJ, Cheung PCK, Cheetham NWH: The carbohydrate composition of cotyledons and hulls of cultivars of Lupinus angustifolius from Western Australia. Journal of the Science of Food and Agriculture 1993; 61: 189-194.
[30] Lee YP, Mori TA, Sipsas S, Barden A, Puddey IB, Burke V, Hall RS, Hodgson JM: Lupin-enriched bread increases satiety and reduces energy intake acutely. Am J Clin Nutr 2006; 84: 975-980.

[31] ICC: ICC Standard Methods. In, International Association for Cereal Chemistry http://www.icc.or.at/, Access date 28/5/2011 2001.

[32] Davidek J, Hrdlicka J, Karvanek M, Pokorny J, Velisek J: Laboratory handbook for foodstuffs. Prague, CR, SNTL-Alfa, 1981.

[33] Arabshahi-Delouee S, Urooj A: Antioxidant properties of various solvent extracts of mulberry (Morus indica L.) leaves. Food Chemistry 2007; 102: 1233-1240.

[34] Ordoñez AAL, Gomez JD, Vattuone MA, Isla MI: Antioxidant activities of Sechium edule (Jacq.) Swartz extracts. Food Chemistry 2006; 97: 452-458.

[35] Kumaran A, Joel Karunakaran R: In vitro antioxidant activities of methanol extracts of five Phyllanthus species from India. LWT Food Science and Technology 2007; 40: 344-352.

[36] Sacchetti G, Maietti S, Muzzoli M, Scaglianti M, Manfredini S, Radice M, Bruni R: Comparative evaluation of 11 essential oils of different origin as functional antioxidants, antiradicals and antimicrobials in foods. Food Chemistry 2005; 91: 621-632.

[37] Lee SC, Kim JH, Jeong SM, Kim DR, Ha JU, Nam KC, Ahn DU: Effect of far-infrared radiation on the antioxidant activity of rice hulls. J Agric Food Chem 2003; 51: 4400-4403.

[38] Re R, Pellegrini N, Proteggente A, Pannala A, Yang M, RiceEvans C: Antioxidant activity applying an improved ABTS radical cation decolorization assay. Free Radic Biol Med 1999; 26: 12311237.

[39] Moore S, Spackman DH, Stein WH: Chromatography of amino acids on sulphonated polystyrene resins: An improved system.. Anal. Chem. 1958; 30: 1185-1190.

[40] FAO/WHO: Energy and protein requirements. InGeneva, Nutrition Report Series No. 935, 2007.

[41] AACC: Cereal Laboratory Methods, Method 46-09. In(Am. Assoc. Cereal Chem., St. Paul, MN), 7th Ed., American Association of Cereal Chemists, 1983.

[42] SAS: SAS Online Doc_9.1. InCary, NC, SAS Institute Inc., 2004.

[43] Martínez-Villaluenga C, Zieliński H, Frias J, Piskuła MK, Kozłowska H, Vidal-Valverde C: Antioxidant capacity and polyphenolic content of high-protein lupin products. Food Chemistry 2009; 112: 84-88.

[44] Ahmad I, Anjum FM, Butt MS: Quality characteristics of wheat varieties grown in Pakistan from 1933-1996. Pak. J. Food Sci. 2001; 11: 1-4.

[45] Favier JC, Ripert JI, Toque C, Feinberg M: Reportoire general des aliments (composition tables). ed 2nd, Paris, Inra Editions, 1995.

[46] Chapleau N, de Lamballerie-Anton M: Improvement of emulsifying properties of lupin proteins by high pressure induced aggregation. Food Hydrocolloids 2003; 17: 273-280.

[47] Huyghe C: White lupin (Lupinus albus L.). Field Crops Research 1997; 53: 147-160.

[48] Nutraingredients: Nutraceutical offers high polyphenol extracts. In http://www.nutraingredients.com/news/ng.asp?id=62581, 2005.

[49] Kosar M, Dorman HJ, Can Baser KH, Hiltunen R: Screening of free radical scavenging compounds in water extracts of Mentha samples using a postcolumn derivatization method. J Agric Food Chem 2004; 5 2: 5004-5010.

[50] Ricardo-da-Silva J, Laureano O, Beirao da Costa M: Total phenol and proanthocyanidin evaluation of Lupinus species. In Proceedings of the VIIth International Lupin Conference,. Evora, Portugal, 1993:250-254.

[51] Oomah BD, Cardador-Martínez A, Loarca-Piña G: Phenolics and antioxidative activities in common beans (Phaseolus vulgaris L). Journal of the Science of Food and Agriculture 2005; 85: 935-942.

[52] Huang D, Ou B, Prior RL: The chemistry behind antioxidant capacity assays. J Agric Food Chem 2005; 53: 1841-1856.

[53] Dorman HJD, Koşar M, Kahlos K, Holm Y, Hiltunen R: Antioxidant Properties and Composition of Aqueous Extracts from Mentha Species, Hybrids, Varieties, and Cultivars. Journal of Agricultural and Food Chemistry 2003; 51: 4563-4569.

[54] Da Porto C, Calligaris S, Celotti E, Nicoli MC: Antiradical properties of commercial cognacs assessed by the DPPH (.) test. J Agric Food Chem 2000; 48: 4241-4245.

[55] Yamaguchi F, Ariga T, Yoshimura Y, Nakazawa H: Antioxidant and antiglycation of carcinol from Garcinia indica fruit rind. J. Agric. Food Chem. 2000; 48: 180-185. 
[56] Wang M, Li J, Rangarajan M, Shao Y, LaVoie EJ, Huang T-C, Ho C-T: Antioxidative Phenolic Compounds from Sage (Salvia officinalis). Journal of Agricultural and Food Chemistry 1998; 46: 4869-4873.

[57] Drakos A, Doxastakis G, Kiosseoglou V: Functional effects of lupin proteins in comminuted meat and emulsion gels. Food Chemistry 2007; 100: 650-655.

[58] Gulewicz P, Martínez-Villaluenga C, Frias J, Ciesiołka D, Gulewicz K, Vidal-Valverde C: Effect of germination on the protein fraction composition of different lupin seeds. Food Chemistry 2008; 107: 830-844.

[59] Pisariková B, Zraly Z, Bunka F, Trckova M: Nutritional value of white lupine cultivar Butan in diets for fattening pigs. Veterinárni Medicina 2008; 53: 124-134.

[60] Lubowicki R, Petkov K, Kotlarz A, Jaskowska I: Chemical composition and nutritive value of protein of lupins seeds. Folia Universitaet Agricultura Zootechnica, Szczecin 2000; 39: 9-104.

[61] Sujak A, Kotlarz A, Strobel W: Compositional and nutritional evaluation of several lupin seeds. Food Chemistry 2006; 98: 711719 .

[62] Molvig L, Tabe LM, Eggum BO, Moore AE, Craig S, Spencer D, Higgins TJV: Enhanced methionine levels and increased nutritive value of seeds of transgenic lupins (Lupinus angustifolius L.) expressing a sunflower seed albumingene. Proceedings of the National Academy of Sciences 1997; 94: 8393-8398.

[63] El-Adawy TA, Rahma EH, El-Bedawey AA, Gafar AF: Nutritional potential and functional properties of sweet and bitter lupin seed protein isolates. Food Chemistry 2001; 74: 455-462.
[64] Tabe L, Higgins TJV: Engineering plant protein composition for improved nutrition. Focus in Protein Science 1998; 3:2 82-285.

[65] Alsmeyer RH, Cunningham AE, Happich ML: Equations predict PER from amino acid analysis. Food Technology 1974; 28: 34-40.

[66] Howard NB: The role of some essential ingredients in the formation of layer cake structures. Bakers Digest 1972; 46: 28-37.

[67] Mizukoshi M, Maeda H, Amano H: Model studies of cake baking, II. Expansion and heat set of cake batter during baking. Cereal Chem 1980; 55: 352-355.

[68] Mohamed S, Hamid NA: Effects of ingredients on the characteristics of rice cakes. Journal of the Science of Food and Agriculture 1998; 76: 464-468.

[69] Sasaki T, Yasui T, Matsuki J: Influence of non-starch polysaccharides isolated from wheat flour on the gelatinization and gelation of wheat starches. Food Hydrocolloids 2000; 14:2 95303.

[70] Dodok L, Modhir AA, Hozova B, Halasova G, Polacek I: Importance and utilization of chickpea in cereal technology. Acta alimentaria 1993; 22: 119-129.

[71] Sabanis D, Makri E, Doxastakis G: Effect of durum flour enrichment with chickpea flour on the characteristics of dough and lasagne. Journal of the Science of Food and Agriculture 2006; 86: 1938-1944.

[72] Alabi MO, Anuonye JC: Nutritional and sensory attributes of soysupplemented cereal meals. Nigerian Food J. 2007; 25: 100-110. 